\title{
Modelling the Performance of Positive P/E firms and Negative P/E firms
}

\author{
$\underline{\text { S. Abidin }}^{\mathrm{a}}$, Y. Ye ${ }^{\mathrm{a}}$ and Z. Zhao ${ }^{\mathrm{a}}$ \\ ${ }^{a}$ Department of Finance, Waikato Management School, University of Waikato, Private Bag 3105, Hamilton \\ 3240, New Zealand \\ Email: sazali@waikato.ac.nz
}

\begin{abstract}
This paper evaluates whether performance of positive P/E firms are significantly different from negative $\mathrm{P} / \mathrm{E}$ firms. It also investigates the characteristics of positive $\mathrm{P} / \mathrm{E}$ firms and negative $\mathrm{P} / \mathrm{E}$ firms and determine whether the differences in characteristics are statistically significant. Both Mood Median test and Kolmogorov-Smirnov (K-S) test are used in this paper to examine the significance of results on data gathered for four Asian countries (China, Japan, South Korea and Singapore) for the period from 2004 to 2014. Findings of this study show that the performance between positive $\mathrm{P} / \mathrm{E}$ firms and negative $\mathrm{P} / \mathrm{E}$ firms was significantly different, especially in terms of stock price returns, EBIT margin, current ratio, cash, assets turnover, EPS growth, EBIT growth, revenue growth, and market capitalization. Such results are partly consistent with previous studies and contribute to this area of study by examining new characteristics between firms with positive $\mathrm{P} / \mathrm{E}$ and negative $\mathrm{P} / \mathrm{E}$.
\end{abstract}

Keywords: Price Earnings ratio, performance, investment, fund management 


\section{INTRODUCTION}

$\mathrm{P} / \mathrm{E}$ Ratio is a widely used valuation ratio for investment analysis in financial market. Academic research has focused on examining the performance of firms with different levels of $\mathrm{P} / \mathrm{E}$ stocks, but there is little research with regards to the performance of negative $\mathrm{P} / \mathrm{E}$ firms, and how this performance compares with the most widely examined positive multiples firms. Besides, negative $\mathrm{P} / \mathrm{E}$ ratios are usually showed as "N/A" in report. However, the negative figure of $\mathrm{P} / \mathrm{E}$ ratio cannot be ignored, as it may contains much information, or problems of a company. Therefore, this paper will pay attention to the firms with negative $\mathrm{P} / \mathrm{E}$ ratio and plans to answer two key questions that 1 ) whether performance of negative $\mathrm{P} / \mathrm{E}$ ratio firms are significantly different from positive $\mathrm{P} / \mathrm{E}$ firms, 2) what characteristics are significantly different between firms with negative $\mathrm{P} / \mathrm{E}$ ratio and positive $\mathrm{P} / \mathrm{E}$ ratio.

This paper focuses on four Asian countries: China, Japan, South Korea and Singapore. Those four countries are playing or had played important role in the world economy, and have strong connections between each other. The data in this paper will cover 29,939 of the observations (6,456 unique companies) with 29,081 positive $\mathrm{P} / \mathrm{E}$ ratio observations and 858 negative $\mathrm{P} / \mathrm{E}$ ratio observations during the period 2004-2014. To evaluate the significance, this paper will use both Mood Median test and Kolmogorov-Smirnov (K-S) test. The results of this paper shows that the performance between negative $\mathrm{P} / \mathrm{E}$ ratio firms and positive $\mathrm{P} / \mathrm{E}$ ratio firms was significantly different, especially in terms of EBIT margin, current ratio, cash, assets turnover, EPS growth, EBIT growth, rev growth, market cap, and return of stock.

The rest of the paper is structured as follows: Section 2 provides literature review in three aspects: priceearnings ratio, relationship between firm performance and $\mathrm{P} / \mathrm{E}$ ratio, and $\mathrm{P} / \mathrm{E}$ ratio analysis in China, Japan, South Korea, as well as Singapore. Section 3 discusses the data sources, sample selection and methodology. Section 4 reports empirical results and gives discussions of findings. Section 5 concludes the whole paper and puts forward suggestions of future studies.

\section{LITERATURE REVIEW}

\subsection{Price-Earnings Ratio}

Price-Earnings Ratio is a widely used valuation ratio, which is calculated as a company's current share price divided by its earnings per share (EPS). As Huang and Wirjanto (2011) said that "the price to earnings (P/E) ratio is arguably one of the most widely used valuation metrics in the financial market"(p.1). The P/E ratio is sometimes known as "price multiple" or "earnings multiple" as it reflects how many times earnings investors are willing to pay for per dollar of earnings (Financial Times, 2014). For example, if a company has a P/E ratio of 20 , it means that an investor is willing to pay $\$ 20$ for $\$ 1$ of current earnings. Kennon (2014) pointed out that value investors have long considered the price earnings ratio (P/E) ratio for short) as a useful metric for evaluating the relative attractiveness of a company's stock price.

\subsection{Relationship between Firm Performance and P/E ratio}

Mathematically, $\mathrm{P} / \mathrm{E}$ ratios are possible to be negative, when the earnings of a company is negative (Conenen, 2012). A negative $\mathrm{P} / \mathrm{E}$ ratio implies that the company is losing money and it is not an attractive investment to investors. Usually, negative $\mathrm{P} / \mathrm{E}$ ratios are showed as "N/A" in report, as companies are not willing to tell investors that they are losing money (Conenen, 2012). However, the authors of this report think that a negative figure of $\mathrm{P} / \mathrm{E}$ ratio cannot be ignored, as it may contains much information, or problems of a company. How a negative $\mathrm{P} / \mathrm{E}$ ratio firm performs is considerable. In addition, some researchers believed that negative $\mathrm{P} / \mathrm{E}$ firms are different to positive $\mathrm{P} / \mathrm{E}$ firms, such as Basu, Chen et al., Fama and French, and Lakonishok et al., so their studies segregated the negative multiple firms from the positive ones (Basu, 1977, Chen et al., 1991, Fama and French, 1992, 1993, 1995, Lakonishok et al., 1994, as cited in Athanassakos, 2014).

However, how negative $\mathrm{P} / \mathrm{E}$ firms differ from those that have a positive $\mathrm{P} / \mathrm{E}$ is still a question. Athanassakos did a research on whether negative $\mathrm{P} / \mathrm{E}$ stocks significantly different from positive $\mathrm{P} / \mathrm{E}$ firms using Canadian stock market data for the period 1985-2010. Athanassakos (2014) found that firms with negative multiples are indeed different from firms with positive multiples in two aspects. First, a relatively small number of firms with negative multiples experience high forward stock returns (Athanassakos, 2014). Second, negative $\mathrm{P} / \mathrm{E}$ firms are different from positive $\mathrm{P} / \mathrm{E}$ firms in firm value, size, liquidity and business risk premiums (Athanassakos, 2014). At the end, Athanassakos (2014) concluded that "prior academic research was correct in excluding negative multiple firms from their analyses" (p.1). Howvwe, Athanassakos (2013) still considered that there is a large body of academic research has examined the performance of firms with 
different levels of positive price-to-earnings (P/E) stocks, but there is not much research with regards to the performance of negative $\mathrm{P} / \mathrm{E}$ firms and how the performance compares with the most widely examined positive multiples firms. Therefore, it is worth to do analysis on performance and characteristic of positive $\mathrm{P} / \mathrm{E}$ ratio and negative $\mathrm{P} / \mathrm{E}$ ratio firms and make contribution on expanding empirical research on this issue.

\subsection{P/E Ratio Analysis in Asia}

Chinese firms' $\mathrm{P} / \mathrm{E}$ ratios have caught much attention recently. It seems that China has a $\mathrm{P} / \mathrm{E}$ ratio comparable to or lower than that in prevailing mature markets, in particular, the U.S. markets (Yu, 2008, as cited in Huang, \& Wirjanto, 2011). According to Huang and Wirjanto's research, China's P/E ratio is comparable to that of the U.S (2011). Specifically, the P/E ratio is negatively associated with earnings volatility in both the Chinese and U.S. stock markets with an economically significant magnitude and historical earnings volatility is considerably higher in China than in the U.S (Huang, \& Wirjanto, 2011). However, Huang and Wirjanto (2011) found that, "compared with the U.S., China exhibits not only larger earnings volatility but also a higher sensitivity of $\mathrm{P} / \mathrm{E}$ to earnings volatility, resulting in a much larger portion of the $\mathrm{P} / \mathrm{E}$ ratio negatively affected by earnings volatility "(p.24). It means that higher earnings volatility in China offsets higher growth prospect in setting the $\mathrm{P} / \mathrm{E}$ ratio, making its $\mathrm{P} / \mathrm{E}$ ratio much closer to what is observed empirically than otherwise implied by its growth rate (Huang, \& Wirjanto, 2011). That is why China's seemingly low $\mathrm{P} / \mathrm{E}$ ratio is not surprising in light of the economic growth that it has experienced (Huang, \& Wirjanto, 2011).

Japanese companies experienced high $\mathrm{P} / \mathrm{E}$ ratios in the history. According to Drysdale and Gower's research, the $\mathrm{P} / \mathrm{E}$ ratio has been observed to be higher in Japan than in the United State ever since the early 1970s because of the lower discount rate in Japan (1999). Meanwhile, Drysdale and Gower (1999) viewed that there are other explanations, such as a higher expected growth rate in Japan. Afterwards, French and Poterba (1991, as cited in Kato, Li, \& Skinner, 2012) found that Japanese companies had high P/E ratios in the 1980s and thought that was partly driven by differences in accounting pushing down EPS numbers, including the fact that most financial statements in Japan were not consolidated. Besides, French and Poterba (1991, as cited in Kato, Li, \& Skinner, 2012) said that these accounting differences had largely disappeared by the early 2000s, which possibly explains at least part of the upward trend in Japanese P/E ratios.

Based on P/E ratio valuation, South Korea was seemed as one of the cheapest markets in the world in 2002. According to Jau and Mahmud (2002), South Korea's valuations was very attractive and close to a historical low in 2002, as it had an average forecast price-earnings (PE) ratio of 7.7 times for 2002, 6.8 times for 2003, and 6.3 times for 2004. Besides, Jau and Mahmud (2002) said that, in 2002, South Korea looked even more attractive relative to other major markets in rest of the world, because South Korea's a forecast PE ratio was only about a third of the US'. In Jau and Mahmud's evaluation, only 2 companies out of the top 15 companies have forecast PE ratios higher than 10 times for 2003, and all except 1 have forecast PE ratios lower than 10 times for 2004 (2002). This study compares between positive P/E ratio firms and negative P/E ratio firms in the selected Asian countries, answering two key questions, that whether performance of negative $\mathrm{P} / \mathrm{E}$ ratio firms are different from positive $\mathrm{P} / \mathrm{E}$ firms, and what characteristics are significantly different between firms with negative $\mathrm{P} / \mathrm{E}$ ratio and positive $\mathrm{P} / \mathrm{E}$ ratio. This paper aims to investigate the relationship between $\mathrm{P} / \mathrm{E}$ ratio and firm performance in Asia, to fill those gaps, and answer the two key questions above.

\section{DATA AND METHODOLOGY}

\subsection{Sample}

The sample of this paper contains four Asian countries: China (CHN), Japan (JPN), South Korea (KOR) and Singapore (SGP). All data is collected from the Thomson One Database. The data of China does not include Hong Kong, which is consistent with the data classify in the Thomson One. The time period for the sample is from 2004 to 2013. And the financial time period is from 2002 to 2012. All the data are calculated and recorded in the USD.

Based on P/E ratio, all firms are divided into two groups. One group contains firms with positive P/E ratio, and another group includes firms with negative $\mathrm{P} / \mathrm{E}$ ratio. The variables to compare the positive and negative P/E ratio are EBIT Margin, Current ratio, Cash, Debt, Turnover, EPS growth, EBIT growth, Sales growth, Market CAP, return and $\mathrm{P} / \mathrm{B}$ ratio. Therefore, the data collected from Thomson One database for four countries are the trailing Earnings per share (EPS), Assets Turnover, Book Value per Share (P/B), Cash and Short Investments, Earning before Interest and Tax (EBIT), growth of EBIT, growth of EPS, Close Price, Sales, Total Assets, Total Debt, Total Investment Return, Market CAP and Current Ratio. 
To eliminate likely data error, according to Fama and French (1992), firms with P/E ratio over 100, or less 100 are deleted. Finally, the sample of this paper is consists of 29,939 of the observations $(6,456$ unique companies) for four countries from 2004 to 2013. 29,081 positive P/E ratio observations with 6,379 unique companies and 858 negative $\mathrm{P} / \mathrm{E}$ ratio observations with 783 unique companies are included in the sample.

\subsection{Methodology}

This paper uses the trailing P/E ratio to do analysis. According to Pratt (2001), the 12 month trailing P/E ratio is the most common and traditional approach for analysis the data from the previous year or next year. The function of trailing $\mathrm{P} / \mathrm{E}$ ratio is

\section{P $/ E(T T M)=\frac{\text { Current Share Price }}{2}$ Trailing Twelve Months Earnings Per Share}

The current share price for this paper is collected on 1 January for each year, because, usually, the fiscal year is from 1 Jan to 31 Dec and 1 January is the start of year. Therefore, the function is also can be written as

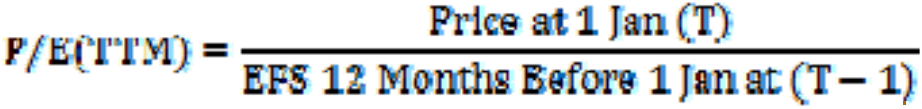

Skewness is used to find the asymmetry of a series of data, which is marked as SKEW in this paper. According to Dictionary of Economics (2009), there are three possible situations.

1) When SKEW $>1$, it means the data is positively skewed and the median result is more accurate than the mean result.

2) When SKWE $<-1$, it means the data is negatively skewed and the median result is more accurate than the mean result.

3) When $1 \geq \operatorname{SKWE} \geq-1$, it means the data is relatively symmetric and the mean result is more accurate than the median result.

To test whether the performance of positive $\mathrm{P} / \mathrm{E}$ ratio and negative $\mathrm{P} / \mathrm{E}$ ratio firms are different, this paper use both Mood Median test and Kolmogorov-Smirnov test. The hypotheses of Moon Median test is:

H0: median of positive companies $=$ median of negative companies.

For K-S test:

H0: population distribution of positive companies = population distribution of negative companies.

For result, if the result in Moon Median test, or K-S test, is 0.05 , it means that the performance of positive $\mathrm{P} / \mathrm{E}$ ratio firms and negative $\mathrm{P} / \mathrm{E}$ ratio firms are equal at 0.05 significant levels. Otherwise, the result rejects the $\mathrm{H} 0$, which means the performance of positive $\mathrm{P} / \mathrm{E}$ ratio firms is different from the performance of negative $\mathrm{P} / \mathrm{E}$ ratio firms.

\section{RESULTS AND DISCUSSIONS}

\subsection{Summary Statistics}

Table 1 and Table 2 are data description for positive P/E ratio firms and negative P/E ratio firms separately. Table 1 shows that the median numbers for each variable are all smaller than the mean numbers in positive $\mathrm{P} / \mathrm{E}$ ratio firms. Similarly for negative $\mathrm{P} / \mathrm{E}$ ratio firms, Table 2 also shows that the median value is smaller than the mean value. Pay attention to the SKEW in the last column, this paper finds that all the value are great than one except the P/E in negative P/E ratio firms. Therefore, Moon Median test and KolmogorovSmirnov test are more suitable for this research.

Comparing Table 1 and Table 2, it is easy to be found that all variables' mean values in firms with negative $\mathrm{P} / \mathrm{E}$ ratio are lower than that in firms with positive $\mathrm{P} / \mathrm{E}$ ratio. The biggest difference occurs in market capitalization. The market capitalization of positive $\mathrm{P} / \mathrm{E}$ ratio firms is 1298.013 on average, while the mean market capitalization of negative $\mathrm{P} / \mathrm{E}$ ratio firms is only 435.473 , which is one-third of firms with positive multiples. Similarly, the comparison of medium value also shows the biggest gap in market capitalization. Besides, positive and negative P/E ratio firms have big differences in debt, EPS growth, one-year stock return. Such results are displayed in Table 3. Whether such differences are significant will be estimated by this paper further through Mood Median test and Kolmogorov-Smirnov test. 
Table 1. Data Description of Positive P/E ratio firms.

\begin{tabular}{|l|l|l|l|l|l|}
\hline Variables & Mean & Median & Max & Min & SKEW \\
\hline EBIT MARGIN & 0.112 & 0.073 & -1.187 & 14.560 & 28.2 \\
\hline Current Ratio & 1.846 & 1.460 & 0.040 & 52.790 & 7.9 \\
\hline CASH & 0.160 & 0.132 & 0.001 & 0.876 & 1.5 \\
\hline Debt & 616.795 & 59.400 & 0.010 & 163977.040 & 18.8 \\
\hline Turnover & 2.005 & 1.226 & 0.050 & 992.800 & 66.1 \\
\hline EPSgrowth & 38.721 & 10.000 & -99.900 & 996.670 & 3.7 \\
\hline EBITgrowth & 0.323 & 0.155 & -523.615 & 986.143 & 65.1 \\
\hline REVgrowth & 0.239 & 0.125 & -0.991 & 672.263 & 131.1 \\
\hline Market CAP & 1298.013 & 231.080 & 0.960 & 775773.350 & 48.0 \\
\hline Return \% & 20.173 & 4.520 & -99.020 & 963.330 & 3.0 \\
\hline P/E & 23.603 & 17.000 & 0.004 & 100.000 & 1.5 \\
\hline P/B & 7.031 & 3.290 & -81.070 & 99.750 & 3.6 \\
\hline
\end{tabular}

Table 2. Data Description of Negative P/E ratio firms.

\begin{tabular}{|l|l|l|l|l|l|}
\hline Variables & Mean & Median & Max & Min & SKEW \\
\hline EBIT MARGIN & 0.041 & 0.026 & -1.051 & 2.033 & 9.258 \\
\hline Current Ratio & 1.608 & 1.270 & 0.100 & 40.020 & 12.986 \\
\hline CASH & 0.129 & 0.105 & 0.001 & 0.644 & 1.669 \\
\hline Debt & 433.830 & 65.415 & 0.030 & 16216.170 & 6.212 \\
\hline Turnover & 1.514 & 1.073 & 0.156 & 26.410 & 7.073 \\
\hline EPSgrowth & -35.531 & -68.585 & -99.980 & 844.780 & 4.434 \\
\hline EBITgrowth & -0.189 & -0.402 & -6.163 & 100.500 & 26.803 \\
\hline REVgrowth & 0.084 & 0.017 & -0.874 & 7.478 & 8.238 \\
\hline Market CAP & 435.473 & 78.525 & 2.760 & 17349.190 & 6.866 \\
\hline Return \% & -11.940 & -20.235 & -91.780 & 603.770 & 4.028 \\
\hline P/E & -33.467 & -27.536 & -100.000 & -0.019 & -0.775 \\
\hline P/B & 6.569 & 3.885 & -74.620 & 83.830 & 2.432 \\
\hline
\end{tabular}

Notes: The first column of the table is the Variables Name. The second column is the mean values of the positive/negative P/E ratio. The third column is the median of the positive/negative P/E ratio. The fourth and fifth column are Max and Min values. The last column is the SKEW.

\subsection{Comparison Analysis}

The results of Mood Median test and Kolmogorov-Smirnov test shows that most of results are significant at $1 \%$, except debt and P/B ratio in K-S test. Such results mean that the null hypothesis both in Mood Median test and K-S test should be rejected, and the performances between positive P/E firms and negative P/E firms are quite different. The differences between positive and negative $\mathrm{P} / \mathrm{E}$ ratio firms are much significant in term of EBIT margin, current ratio, cash, assets turnover, EPS growth, EBIT growth, rev growth, market cap, and return of stock. 
S. Abidin et al., Modelling the Performance of Positive P/E firms and Negative P/E firms

Table 3. Mean and Median Comparisons between Positive and Negative Firms.

\begin{tabular}{|c|c|c|c|c|c|c|}
\hline \multirow[b]{2}{*}{ Variables } & \multicolumn{3}{|l|}{ Mean } & \multicolumn{3}{|l|}{ Median } \\
\hline & $\begin{array}{l}\text { Positive } \\
\mathrm{P} / \mathrm{E} \text { ratio } \\
\text { firms }\end{array}$ & $\begin{array}{l}\text { Negative } \\
\mathrm{P} / \mathrm{E} \text { ratio } \\
\text { firms }\end{array}$ & Difference & $\begin{array}{l}\text { Positive } \\
\mathrm{P} / \mathrm{E} \text { ratio } \\
\text { firms }\end{array}$ & $\begin{array}{l}\text { Negative } \\
\mathrm{P} / \mathrm{E} \text { ratio } \\
\text { firms }\end{array}$ & Difference \\
\hline EBIT MARGIN & 0.112 & 0.041 & 0.071 & 0.073 & 0.026 & 0.047 \\
\hline Current Ratio & 1.846 & 1.608 & 0.238 & 1.46 & 1.27 & 0.19 \\
\hline $\mathrm{CASH}$ & 0.16 & 0.129 & 0.031 & 0.132 & 0.105 & 0.027 \\
\hline Debt & 616.795 & 433.83 & 182.965 & 59.4 & 65.415 & -6.015 \\
\hline Turnover & 2.005 & 1.514 & 0.491 & 1.226 & 1.073 & 0.153 \\
\hline EPSgrowth & 38.721 & -35.531 & 74.252 & 10 & -68.585 & 78.585 \\
\hline EBITgrowth & 0.323 & -0.189 & 0.512 & 0.155 & -0.402 & 0.557 \\
\hline REVgrowth & 0.239 & 0.084 & 0.155 & 0.125 & 0.017 & 0.108 \\
\hline Market CAP & 1298.013 & 435.473 & 862.54 & 231.08 & 78.525 & 152.555 \\
\hline Return \% & 20.173 & -11.94 & 32.113 & 4.52 & -20.235 & 24.755 \\
\hline $\mathrm{P} / \mathrm{E}$ & 23.603 & -33.467 & 57.07 & 17 & -27.536 & 44.536 \\
\hline $\mathrm{P} / \mathrm{B}$ & 7.031 & 6.569 & 0.462 & 3.29 & 3.885 & -0.595 \\
\hline
\end{tabular}

\section{CONCLUSIONS}

Using data of four Asian countries: China, Japan, South Korea and Singapore for the period 2004-2014, with 29,939 observations $(6,456$ unique companies), the purpose of this paper was to examine whether the performance of negative $\mathrm{P} / \mathrm{E}$ ratio firms were significantly different from positive $\mathrm{P} / \mathrm{E}$ ratio firms, and what characteristics are between negative and positive $\mathrm{P} / \mathrm{E}$ ratio firms. To do that this paper used both Mood Median test and Kolmogorov-Smirnov (K-S) test. This paper found that the performance between negative $\mathrm{P} / \mathrm{E}$ ratio firms and positive $\mathrm{P} / \mathrm{E}$ ratio firms was significantly different, especially in terms of EBIT margin, current ratio, cash, assets turnover, EPS growth, EBIT growth, rev growth, market cap, and return of stock. Such results were partly consistent with previous studies that firms with negative multiples are indeed different from firms with positive multiples, and the value, size, liquidity and business risk premiums behave differently for negative and positive P/E firms (Athanassakos, 2014).

\section{REFERENCES}

Athanassakos, G. (2013). Are Negative P/E and P/B ratio firms different? Business \& Financial Affairs, 1(2), 1-4. doi:10.4172/2167-0234.1000109.

Athanassakos, G. (2014). Are negative P/E ratio firms different from positive P/E firms? The case of inter listed vs. non-interlisted firms in Canada. The Journal of Financial Perspectives, 2(2), 1-11.

Conenen, J. (2012, April 20). Personal Finance \& Money Stack Exchange- What is the P/E ratio for a company with negative earnings? [Online forum comment]. Retrieved from http://money.stackexchange.com/questions/14576/what-is-the-p-e-ratio-for-a-company-with-negativeearnings.

Drysdale, P., \& Gower, L. (1999). Routledge Library of Modern Japan. The Japanese Economy Part 2(5), Retrieved from http://books.google.co.nz/books.

Emamgholipour, M., Pouraghajan, A., Tabari, N. A. Y., Haghparast, M., \& Shirsavar, A. A. A. (2013). The effect of performance evaluation market ratios on the stock return: evidence from the Tehran stock exchange. International Research Journal of Applied and Basic Sciences, 4. 
S. Abidin et al., Modelling the Performance of Positive P/E firms and Negative P/E firms

Fama, E. F., and French, K. R. (1992) The Cross Section of Expected Stock Returns. Journal of Finance 47: 427-465.

Financial Times (2014). Defination of price/earnings ratio. Retrieved from http://lexicon.ft.com/Term?term=price/earnings-ratio

Huang, A.G., \& Wirjanto, T.S. (2011). Is China's P/E Ratio too Low? Examining the Role of Earnings Volatility. Retrieved from http://arts.uwaterloo.ca/ aghuang/research-/PEratio.pdf.

Jau, W. S., \& Mahmud, S. (2002). South Korea - One Of The Cheapest Markets In The World. Retrieved from https://secure.fundsupermart.com/main/article/South-Korea-One-Of-The-Cheapest-Markets-In-TheWorld-915.

Kato, K., Li, M., \& Skinner, D. J. (2012). Is Japan Really a" Buy"? The Corporate Governance, Cash Holdings, and Economic Performance of Japanese Companies. Center on Japanese Economy and Business Working Papers. Retrieved from http://academiccommons.columbia.edu/catalog/ac\%3A152593.

Kennon, J. (2014). P/E Ratio: Using the Price-to-Earnings Ratio as a Quick Way to Value a Stock. Retrieved from http://beginnersinvest.about.com/cs/valueinvesting1/a/011101a.htm.

Pratt, M. K. (2001). Price-to-earnings ratio. Computerworld, 35(29), 44. Retrieved from http://ezproxy.waikato.ac.nz/login?url=http://search.proquest.com/docview/216079583?accountid=17287

Tabassum, N., Kaleem, A., \& Nazir, M. S. (2013). Impact of Real Earnings Management on Subsequent Financial Performance. Middle-East Journal of Scientific Research, 17(4), 551-560. 